\title{
The Effect of Ownership Structure and Financial Performance on Firm Value with Dividend Policy as Moderating Variable at Property and Real Estate Companies
}

\author{
Witya Shalini ${ }^{1)^{*}}$, Erlina $^{2)}$, Prihatin Lumban Raja ${ }^{3)}$ \\ ${ }^{1), 2), 3)}$ Faculty of Economics and Business , University of Sumatera Utara,Medan,Indonesia
}

\begin{abstract}
This study aims to determine managerial ownership, institutional ownership, liquidity, leverage, and profitability on firm value with dividend policy as a moderating variable. This type of research is explanatory research with a quantitative approach. The population used in this study are property and real estate companies listed on the Indonesia Stock Exchange from 2010 to 2018. The sampling technique uses purposive sampling so that the selected sample is 16 companies. This study uses descriptive statistical data analysis and multiple linear regression analysis. The results of this study indicate that 1). Managerial Ownership, Institutional Ownership, and Liquidity do no effect on Company Value. 2). Leverage has a negative and significant impact on Company Value. 3). Profitability has a positive and significant impact on Company Value. 4). Dividend Policy cannot moderate the effect of the Managerial Ownership relationship on Company Value. 5). Dividend policy can partially influence the relationship of Institutional Ownership, Liquidity, Leverage, and Profitability to Company Value.
\end{abstract}

Keywords:- Managerial Ownership, Institutional Ownership, Liquidity, Leverage, Profitability, Dividend Policy, Company Value.

\section{INTRODUCTION}

One sector of the company that is overgrowing and has quite fierce competition listed on the IDX is property and real estate sector companies. Investments in property and real estate are desirable to the public. Property and real estate have high added value, increase annual income, increase land values, and are long-term investments. The increasing population growth in Indonesia has led to increased housing, offices, shopping centers, hotels, etc. It guarantees that the demand for property and real estate is rising while the amount of land is limited, causing land prices to increase.

The performance of property companies throughout 2015-2018 experienced a slowdown because it was faced with severe challenges. Sluggish economic conditions and fluctuations in exchange rates have eroded revenues and net profits of this sector. The low property growth has made the sector's stock price index also go down. The slowdown in the property and real estate sector occurred due to the people, which impacted economic conditions. Besides, the impact of the rupiah's impact weakening against the dollar is also a factor in inhibiting this growth. This attenuation continues until 2018. Government and Bank Indonesia (BI) policies also have an impact on this company, one of which is still high-interest rates, which makes it difficult for companies to obtain capital and the imposition of Value Added Tax on Luxury Goods (PPnBM) for homes above Rp 5 billion weaken the property and real estate sector.

Beginning in 2015, the property stock index on the Indonesia Stock Exchange was at the level of 532.96 (https://invest.kontan.co.id/). This index had risen to touch the highest level at the end of February to 582.61. The property sector's made the stock index go down, even reaching 490.93 at the end of December 2015. In 2016, sales at all developer companies experienced a decline or stagnation. It can be seen from the sales data of property and real estate companies listed on the IDX. This index risen to reach the highest level at the end of August 2016 to 598.95 then decreased to 517.81 at the end of December 2016. In 2017-2018, the index of property and real estate stocks continued to decline. At the beginning of 2017, the index opened at 516.23 and closed to 495.51 at the end of December 2017. This decline was followed again until the end of 2018 at 447.75 .

During the year to date, shares in the property and real estate sector recorded a significant decline. Stocks in this sector decreased by $-14.70 \%$ (https://id.investing.com/indices/idx-cons.-property---realestate-historical-data). The slowdown in the property and real estate sector recorded a decrease in the valuation of its shares. Amid the still harmful industry, most investors relinquish their shares in the property and real estate sector and shift their investments in stocks in other areas.

Based on the description and phenomena above, the researcher is interested in researching the titles: "The Effect of Ownership Structure and Financial Performance on Firm Value with Dividend Policy as a Moderating Variable in Property and Real Estate Companies Listed on the Indonesia Stock Exchange. 


\section{LITERATURE REVIEW}

\section{A. The value of the company}

Maximizing shareholder wealth is one of the company's goals that cannot be ignored. The company's market value is an essential measure of shareholder wealth (Gill, 2016). The higher the stock price, the higher its value (Tui et al., 2017). High company value can make the market believe in its current performance and the company's prospects. Market value can be influenced by choice, behavior, psychological, takeover competition, economic change, economic development, political conditions, and so on (Sudana, 2011). The company's stock price can be known to be above, below, or the book's fair value.

\section{B. Managerial Ownership}

In agency theory, the relationship between managers and shareholders is described as the relationship between agent and principal (Vintilă \& Gherghina, 2015). Managerial ownership describes a dual role, namely as a manager and also a shareholder, where each has an interest. Differences in benefits between the two often lead to a conflict called agency conflict (Kouki, 2011). This agency conflict can be minimized by increasing share ownership by management and increasing dividends to be distributed (Carstens \& Wesson, 2019). But to meet both of them will require a substantial source of funding. The principal and agent have interests that are not much different, namely to improve the welfare of each party. Principals and agents tend to have behaviors to reduce corporate debt (Fahmi, 2014). The higher the company's share ownership by management, the higher the manager's response to be careful about the use of debt (Gill, 2016).

\section{Institutional Ownership}

Institutional ownership is the percentage of share ownership by institutional investors such as banks, investment companies, and insurance companies, and other institutions. The monitoring mechanism will guarantee an increase in shareholder prosperity (Fahmi, 2014). Hartzell and Starks' research (Vintilă \& Gherghina, 2015) concludes that institutional ownership structure can affect managerial compensation performance. Institutional ownership has an essential meaning in overseeing management with more optimal supervision of various critical decisions. Including corporate debt policy decisions, institutional shareholders will influence decision making. In addition to ownership of shares, this institutional investor also took part in the vote.

At the general meeting of shareholders (GMS). The high institutional shares level will result in more intensive supervision efforts to limit the manager's opportunistic behavior (Fahmi, 2014). The percentage of share ownership can measure institutional ownership by the company's institutional institution towards the number of shares outstanding (Vintilă \& Gherghina, 2015).

\section{Liquidity}

According to (Horne, 2012) liquidity ratios are ratios that measure a company's ability to meet its short-term liabilities. According to (Fahmi 2014), analyzing liquidity risk can be done by analyzing a company's cash flow analysis, analyzing short-term liabilities, and analyzing short-term fund flows. Liquidity risk can be reduced by strengthening the value of the liquidity ratio (Sudana, 2011).

\section{E. Leverage}

Leverage is a ratio to measure how a company's assets are financed with liabilities (Kasmir, 2008). Leverage is used to measure its ability to pay all of its obligations, both short and long term. Financial managers can adopt policies that are considered necessary for balancing the use of capital. A company is solvable if its total assets are more significant than its liabilities (Kasmir, 2012).

\section{F. Profitability}

Profitability is a ratio to assess a company's ability to generate profits (Kasmir, 2012). Profit is a source of payment of interest and principal for loans for creditors. For equity investors, profit is one of the determinants of changes in the value of securities. Investors prefer companies with high profitability because they assume that the company can provide high investment returns with high profitability.

\section{$>$ Dividend Policy}

If dividends are increased, cash flow for investors will increase, which can benefit investors, whereas if the dividends are increased, retained earnings for investment and future growth will decrease to the detriment of investors (Brigham, Eugene F, 2006). Dividend policy is said to be optimal if it can balance these two things and maximize stock prices (Mery et al., 2017)

\section{G. Framework}

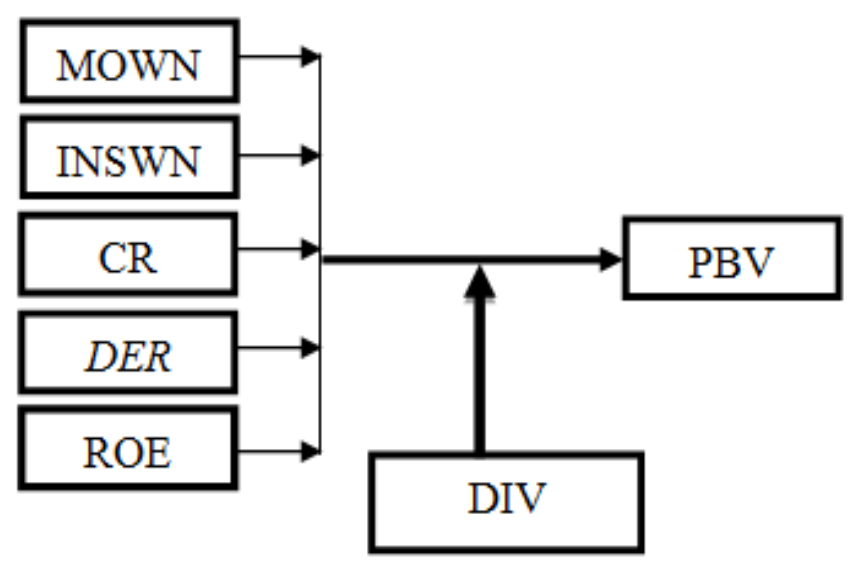

Fig 1 


\section{H. Hypothesis}

H1: Managerial ownership negatively influences firm value.

H2: Institutional ownership positively influences firm value.

H3: Liquidity positively influences firm value.

H4: Leverage negatively influences firm value.

H5: Profitability positively influences firm value.

H6: Dividend Policy Relations Moderate the Effect of Managerial Ownership on firm value.

H7: Dividend Policy Relations Moderate the Effect of Institutional Ownership on firm value.

H8: Dividend Policy Relations Moderate the Effect of Liquidity on firm value.

H9: Dividend Policy Relations Moderate the Effect of Leverage on firm value.

H10: Dividend Policy Relations Moderate the Effect of Profitability on firm value.

\section{RESEARCH METHODOLOGY}

\section{A. Research Approach}

This type of research used in this research is associative research to analyze the effect ownership structure, financial performance on firm value, and whether dividend policy can moderate the impact ownership structure and financial return on firm value. Associative research is research that aims to determine the effect or also the relationship between two or more variables (Sugiyono, 2011). This research has the highest level compared to descriptive and comparative analysis because this research can build a theory that can function to explain, predict, and control a symptom.

\section{B. Data Analysis Methods}

The data analysis method used in this study is a statistical analysis method using SPSS software. Data analysis was performed by testing standard assumptions and testing hypotheses.

\section{RESULT}

\section{A. Regression Equations}

In this research, regression analysis is used to determine whether there is an influence of independent variables, namely managerial ownership, institutional ownership, liquidity, leverage, and profitability on the dependent variable, which is firm value with dividend policy as a moderating variable.

\begin{tabular}{|c|c|c|c|c|}
\hline Variable & Coefficient & Std. Error & t-Statistic & Prob. \\
\hline \hline C & 1385.833 & 806.3226 & 1.718708 & 0.0879 \\
\hline MOWN(X1) & -1385.873 & 806.3627 & -1.718672 & 0.0879 \\
\hline INSWN(X2) & -1386.113 & 806.3467 & -1.719003 & 0.0879 \\
\hline CR(X3) & -0.037140 & 0.098036 & -0.378839 & 0.7054 \\
\hline DER(X4) & -1.027298 & 0.249897 & -4.110880 & 0.0001 \\
\hline ROE(X5) & 6.342110 & 1.316908 & 4.815908 & 0.0000 \\
\hline DIVIDEN(Z) & 0.737844 & 0.269764 & 2.735142 & 0.0071 \\
\hline R-squared & 0.334942 & Mean dependent var & 1.658673 \\
\hline Adjusted R-squared & 0.305815 & S.D. dependent var & 1.832243 \\
\hline S.E. of regression & 1.526583 & Akaike info criterion & 3.731331 \\
\hline Sum squared resid & 319.2725 & Schwarz criterion & 3.875697 \\
\hline Log likelihood & -261.6558 & Hannan-Quinn criter. & 3.789993 \\
\hline F-statistic & 11.49951 & Durbin-Watson stat & 0.619285 \\
\hline Prob(F-statistic) & 0.000000 & \multicolumn{2}{|c|}{} & \\
\hline
\end{tabular}

Table 1:- Results of Regression Analysis

\section{B. Partial Significance Test (Statistical Test $-t$ )}

$>$ Managerial Ownership $(\mathrm{MOWN})$ has tcount $=$ $1.718672>$ ttable $=-1.97743$, with a significance level of $0.0879>\alpha=0.05$, it can be concluded that Managerial Ownership (MOWN) does not significantly influence the Company's Value. So H1 was rejected.

$>$ Institutional Ownership (INSWN) has $\mathrm{t}$ count $=$ $1.719003<$ ttable $=-1.97743$, with a significance level of $0.0879>\alpha=0.05$, it can be concluded that Institutional Ownership (INSWN) has no significant effect on Value Company. So H2 is rejected.

$>$ Liquidity $(\mathrm{CR})$ has tcount $=-0.378839<$ ttable $=$ 1.97743 , with a significance level of $0.07054>\alpha=0.05$, it can be concluded that Liquidity (CR) does not significantly influence the Company Value. So H3 is rejected.

$>$ Leverage $($ DER) has tcount $=-4.110880<$ ttable $=$ 1.97743 , with a significance level of $0.0001<\alpha=0.05$, it can be concluded that Leverage (DER) has a significant and negative effect on Company Value. So H4 is accepted.

Profitability $($ ROE $)$ has a tcount $=4.815908<$ ttable $=$ 1.97743, with a significance level of $0.0000<\alpha=0.05$, it can be concluded that the profitability variable (ROE) significantly and positively influences the Company Value. So H5 is accepted. 


\section{Coefficient of Determination}

The statistical test of the coefficient of determination in this study aims to determine how far the model's ability of the model explains the dependent variable's variation. Statistical test results of the coefficient of determination can be seen in Table 1.

Table 1. shows that the Adjusted R Square value of 0.305815 or $30.5815 \%$, which means that the percentage of influence of the independent variable (Managerial Ownership, Institutional Ownership, Liquidity, Leverage, and Profitability) to the Firm Value is the value of the coefficient of determination or $30.5815 \%$. In comparison, the remaining $69.4185 \%$ is influenced or explained by other variables not included in this research model.

\section{Moderate Regression Analysis (MRA) Test}

MRA test is used to test the hypothesis (6-10), namely that dividend policy can moderate the influence between managerial ownership, institutional ownership, liquidity, leverage, and ROE on firm value. Here are the results of calculations using Eviews:

\begin{tabular}{|c|c|c|c|c|}
\hline Variable & Coefficient & Std. Error & t-Statistic & Prob. \\
\hline $\mathrm{C}$ & 803.5835 & 793.8952 & 1.012203 & 0.3133 \\
\hline MOWN (X1) & -804.6163 & 793.8956 & -1.013504 & 0.3127 \\
\hline INSWN (X2) & -804.4987 & 793.8946 & -1.013357 & 0.3127 \\
\hline $\mathrm{CR}(\mathrm{X} 3)$ & 0.250135 & 0.157477 & 1.588390 & 0.1146 \\
\hline DR $(\mathrm{X} 4)$ & -1.583255 & 0.284212 & -5.570690 & 0.0000 \\
\hline MOWN(X1)DIV(Z) & 6.308373 & 6.140312 & 1.027370 & 0.3061 \\
\hline INSWN(x2)DIV(Z) & 2.499200 & 0.711065 & 3.514729 & 0.0006 \\
\hline $\mathrm{CR}(\mathrm{X} 3) \mathrm{DIV}(\mathrm{Z})$ & -0.469603 & 0.196919 & -2.384757 & 0.0185 \\
\hline DR(X4)DIV(Z) & -1.768864 & 0.542062 & -3.263213 & 0.0014 \\
\hline ROE(X5)DIV(Z) & 4.359139 & 2.525461 & 2.726076 & 0.0067 \\
\hline R-squared & 0.410158 & \multicolumn{2}{|c|}{ Mean dependent var } & 1.658673 \\
\hline Adjusted R-squared & 0.365808 & \multicolumn{2}{|c|}{ S.D. dependent var } & 1.832243 \\
\hline S.E. of regression & 1.459127 & \multicolumn{2}{|c|}{ Akaike info criterion } & 3.666868 \\
\hline Sum squared resid & 283.1640 & \multicolumn{2}{|c|}{ Schwarz criterion } & 3.893729 \\
\hline Log likelihood & -253.0145 & \multicolumn{2}{|c|}{ Hannan-Quinn criter. } & 3.759051 \\
\hline F-statistic & 9.248394 & \multicolumn{2}{|c|}{ Durbin-Watson stat } & 0.780750 \\
\hline Prob(F-statistic) & 0.000000 & & & \\
\hline
\end{tabular}

Table 2:- Results of Regression Analysis With Moderating Variable

From the Eviews calculations, it can be concluded the influence of the moderation variable is as follows:

Dividend Policy on the effect of Managerial Ownership (MOWN) on Company Value.

Managerial Ownership (MOWN) has $t$ count $1.027370<$ ttable 1.97796 , with a significance level of $0.3061>\alpha=0.05$, it can be concluded that Dividend Policy cannot moderate the effect of Managerial Ownership on Company Value. So H6 is rejected

Dividend Policy on the effect of Institutional Ownership (INSWN) on Company Value.

Institutional Ownership (INSWN) has a value of 3.514729> $t$ table 1.97796, with a significance level of $0.0006>\alpha=0.05$, it can be concluded that the Dividend Policy can moderate the effect of Institutional Ownership (INSWN) on Company Value. So H7 is accepted
Dividend Policy on the effect of Liquidity (CR) on Company Value.

Liquidity (CR) has a t $-2,384757<$ ttable $-1,97796$, with a significance level of $0.0185>\alpha=0.05$, it can be concluded that the Dividend Policy can moderate the effect of Liquidity (CR) on Company Value. So H8 is accepted.

Dividend Policy on the effect of Leverage (DER) on Company Value.

Leverage (DER) has $\mathrm{t}-3.263213<$ ttable -1.97796 , with a significance level of $0.0014>\alpha=0.05$, it can be concluded that the Dividend Policy can moderate the effect of the Leverage (DER) variable on Company Value. So H9 is accepted.

Dividend Policy on the effect of Profitability (ROE) on Company Value.

Profitability (ROE) has tcount 2.7726076> t table 1.97796, with a significance level of $0.0067>\alpha=0.05$, it can be concluded that the Dividend Policy can moderate the effect of the Leverage (DER) variable on Company Value so that $\mathrm{H} 10$ is accepted. 


\section{CONCLUSION AND RECOMMENDATION}

\section{A. Conclusions}

From the research and discussion result that has been carried out, conclusions can be drawn as follows:

$>$ Managerial ownership does not significantly influence the Company's Value in the Property and Real Estate companies listed on the Indonesia Stock Exchange in 2010-2018. This indicates that the company's management will still try to work optimally to provide welfare for shareholders or investors without considering managerial ownership. The management believes that regardless of the level of ownership by managerial shares, they will still get bonuses and salary increases by maintaining and improving their performance.

$>$ Institutional ownership does not significantly influence the value company's value in property and real estate companies listed on the Indonesia Stock Exchange in 2010-2018. It indicates that the weakness of the mechanism of monitoring the opportunistic actions of managers in running the company. It can occur because institutional parties tend to compromise with management and thus fail to build a good company reputation by ignoring minority investors' welfare.

- Liquidity has no significant effect on the value company value's in property and real estate companies listed on the Indonesia Stock Exchange in 2010-2018. It indicates that investor does not pay attention to the current ratio factor, because investors consider this ratio only shows the company's ability to pay off short-term debts of a company and investors look more at how the company's management uses the funds effectively and efficiently to achieve added value for the company's value.

$>$ Leverage has a significant and negative effect on the value company's value in property and real estate companies listed on the Indonesia Stock Exchange in the period 2010-2018. This indicates that a company with a high level of debt will increase the company's burden on creditors, and the risk of default will also be high and can reduce corporate profits. The negative influence of leverage on the value of the company shows that investors highly consider the size of the debt owed by the company because investors would want the prospect of high returns, but they are reluctant to face risks. So investors tend to invest less in these companies by diverting their investment to other companies, which can decrease the value of the company in companies with high degree of leverage.

$>$ Profitability has a significant and positive effect on the value company's value in property and real estate companies listed on the Indonesia Stock Exchange in the period 2010-2018. This indicates that profitability shows the level of net profit that can be achieved by the company when running its operations. Profits worth sharing with shareholders are profits after interest and taxes. High profitability can provide added value to the value company' value and maintain a consistent level of a company growth can increase the company's profitability, which will trigger a demand for shares by investors, which is reflected in its share price and can increase the company's value.

$>$ Dividend Policy cannot moderate the Managerial Ownership relationship on Company Value in the Property and Real Estate companies listed on the Indonesia Stock Exchange in the period 2010-2018. Proportional managerial ownership structure affects a variety of corporate financial decisions. One of them is the company's dividend policy decision. Shareholders give this authority to the board of directors who are part of the company's management. But this cannot be used as a reference if the proportion of share ownership by management is still relatively low so the agent cannot contribute fully to the decision on dividend distribution.

$>$ Dividend policy can moderate the effect of the relationship of Institutional Ownership on Company Value on Property and Real Estate companies listed on the Indonesia Stock Exchange in the period 2010-2018. This indicates that high institutional ownership can affect management decisions, one of which is the decision to distribute profits as dividends to be distributed to investors. High institutional ownership, the dividends distributed are also high. Companies that distribute high dividends show the prospects of the company both in the eyes of investors and the public (Aditya \& Supriyono, 2015).

$>$ Dividend Policy can moderate the Liquidity relationship on Company Value in Property and Real Estate companies listed on the Indonesia Stock Exchange in the period 2010-2018. This indicates that the greater the current ratio shows the higher the company's ability to meet its short-term obligations. The high current ratio shows investors' confidence in the company's ability to pay the promised dividend because the availability of assets shows the level of dividend payment. The current ratio position is an important variable to consider by management when deciding on dividend policy.

$>$ Dividend Policy can moderate the Leverage relationship on Company Value in the Property and Real Estate companies listed on the Indonesia Stock Exchange in the period 2010-2018. This indicates that the dividend policy can increase the company's value when leverage is high, and the dividend policy can increase the value of the company when leverage is high.

> Dividend Policy can moderate the profitability relationship on Company Value in Property and Real Estate companies listed on the Indonesia Stock Exchange in the period 2010-2018. This indicates that profitability is the primary determinant of the consideration of dividend payments. The higher the profitability, shows better the management in carrying out the company's operations. Companies that have high profitability will usually distribute high dividends as well, and the increase in company value will also be reflected in the company's ability to distribute dividends. 


\section{B. Suggestions}

For the next research it is recommended not to use the current ratio, because the ratio only measures current assets with current debt, not taking into account the overall total assets and total liabilities of the company. Leverage and profitability variables need attention both for investors and potential investors to assess a company.

As for property and real estate companies, they need to pay attention to liquidity in order to have financial flexibility in achieving good corporate value for the company's external parties. For listed companies, companies should increase company value so they can attract investors to invest in their companies, and listed companies should also be able to increase the profitability of their companies so that financial performance is good in the eyes of investors.

\section{REFERENCES}

[1]. Aditya, D., \& Supriyono, E. (2015). Pengaruh Profitabilitas dan Kepemilikan Institusional Terhadap Nilai Perusahaan Dengan Kebijakan Dividen Sebagai Variabel Intervening Pada Perusahaan Manufaktur yang Terdaftar di Bursa Efek Indoensia Periode 2010-2014. Jurnal

Manajemen Bisnis, 6(1), 307-326.

[2]. Brigham, E. F., and Houston, J. F. (2001). Manajemen Keuangan (Kedelapan). Salemba Empat.

[3]. Brigham, E.F., and H. F. J. (2002). Fundamentals of Financial Management (D. S. dan H. Wibowo (ed.); Kedelapan). Erlangga.

[4]. Brigham, Eugene F, G. dan L. C. (2006). Intermediate Financial Management. The Dryden Press.

[5]. Budianto, W., \& Payamta, P. (2014). Pengaruh Kepemilikan Manajerial Terhadap Nilai Perusahaan Dengan Kebijakan Dividen Sebagai Variabel Moderasi. Assets: Jurnal Akuntansi Dan Pendidikan, 3(1), 13. https://doi.org/10.25273/jap.v3i1.1207

[6]. Carstens, R., \& Wesson, N. (2019). The impact of South African real estate investment trust legislation on firm growth and firm value. South African Journal of Economic and Management Sciences, 22(1),

$1-9$. https://doi.org/10.4102/sajems.v22i1.2257

[7]. Du, J., Wu, F., \& Liang, X. (2016). Corporate liquidity and firm value: evidence from China's listed firms. SHS Web of Conferences, 24, 01013.

https://doi.org/10.1051/shsconf/20162401013

[8]. Fahmi, I. (2014). Manajemen Keuangan Perusahaan. Mitra Wacana Media.

[9]. Fajaria, A. Z. (2018). The Effect of Profitability, Liquidity, Leverage and Firm Growth of Firm Value with its Dividend Policy as a Moderating Variable. International Journal of Managerial Studies and Research, 6(10), 55-69. https://doi.org/10.20431/2349- $\quad 0349.0610005$
[10]. Ghozali, I. (2005). Aplikasi Analisis Multivariate dengan Program SPSS. Universitas Diponegoro.

[11]. Gill, A. (2016). The Impact of Corporate Governance and Financial Leverage on Value of Firms Listed on [12]. Amman Stock Exchange. Jordan Journal of Business Administration, 12(4), 899-917. https://doi.org/10.12816/0034973

[12]. Gultom, R., \& Wijaya, S. W. (2013). Analisis Faktor Faktor yang Mempengaruhi Nilai Perusahaan Farmasi di Bursa Efek Indonesia periode 20082011. Jurnal Wira Ekonomi Mikroskil, 3(1), 51-60.

[13]. Handayani, I. A. R. P., Ariyanto, D., Rasmini, N. K., \& Widanaputra, A. A. G. P. (2018). The Effect of Profitability, Institutional Ownership on the Value of the Company with Dividend Policy as a Meditation. Sciences: Basic and Applied Research, 41(1), 234- 242.

[14]. Harahap, S. S. (2004). Analisis Laporan Kritis Keuangan. Jakarta : Rajawali Grafindo.

[15]. Harningsih, S., Agustin, H., Setiawan, M. A., Padang, U. N., Barat, A. T., Padang, U. N., Barat, A. T., Padang, U. N., Barat, A. T., \& Perusahaan, N. (2019). Pengaruh Kinerja Keuangan Terhadap Nilai Perusahaan Variabel Moderasi. Journal of Multidisciplinary

Reserch and Development, 2655- 0865, 199209.

[16]. Haruman. (2008). Struktur Kepemilikan, Keputusan Keuangan, dan Nilai Perusahaan. Finance and Banking Journal, 10(2), 150-166.

[17]. Hermuningsih, S. (2014). Profitability, Growth Opportunity, Capital Structure and the Firm Value. Buletin Ekonomi Moneter Dan Perbankan, 16(2), 115-136. https://doi.org/10.21098/bemp.v16i2.440

[18]. Hidayah, N. (2017). Pengaruh Investment Opportunity Set (Ios) Dan Kepemilikan Manajerial Terhadap Nilai Perusahaan Pada Perusahaan Property Dan Real Estat Di Bursa Efek Indonesia. Jurnal Akuntansi, 19(3), 420. https://doi.org/10.24912/ja.v19i3.89

[19]. Horne, J. C. V. dan J. M. W. (1997). Prinsip-Prinsip Manajemen Keuangan (Pertama). Salemba Empat.

[20]. Horne, J. C. V. dan J. M. W. (2012). Prinsip-Prinsip Manajemen Keuangan. Salemba Empat.

[21]. Hung, D. N., Cuong, P. D., \& Bich Ha, V. T. (2018). Effects of financial statements information on firms' value: Evidence from Vietnamese listed firms. Investment Management and Financial Innovations, $15(4)$, https://doi.org/10.21511/imfi.15(4).2018.17

[22]. Husna, A., \& Satria, I. (2019). Effects of Return on Asset, Debt To Asset Ratio, Current Ratio, Firm Size, and Dividend Payout Ratio on Firm Value. International Journal of Economics and Financial Issues, 9(5), 50-54. https://doi.org/10.32479/ijefi.8595 
[23]. Isti'adah, U. (2015). Faktor-faktor yang mempengaruhi nilai perusahaan pada perusahaan non keuangan. JURNAL NOMINAL, IV(2), 57-72. https://doi.org/10.34208/jba.v19i1.67

[24]. Jensen, M. C., \& Meckling, W. H. (1976). Theory Of The Firm: Managerial Behavior, Agency Costs And Ownership STRUCTURE. Journal of Financial Economics.

[25]. Jonathan, S. (2006). Metode Penelitian Kuantitatif dan Kualitatif. Graha Ilmu.

[26]. Kasmir. (2008). Analisa Laporan Keuangan. PT Raja Grafindo Persada.

[27]. Kasmir. (2012). Analisis Laporan Keuangan. PT Raja Grafindo Persada.

[28]. Kasmir. (2014). Analisis Laporan Keuangan (Pertama). PT Raja Grafindo Persada.

[29]. Kouki, M. (2011). Does Management Ownership Explain The Effect Of Leverage On Firm Value? An Analysis Of French Listed Firms Hatem ben Said. Journal of Business Studies Quarterly, 3(1), 169186.

[30]. Liang, C. J., Huang, T. T., \& Lin, W. C. (2011). Does ownership structure affect firm value? Intellectual capital across industries perspective. Journal of Intellectual Capital, 12(4), 552-570. https://doi.org/10.1108/14691931111181724

[31]. Mahendra, A., Artini, L. G. S., \& Suarjaya, A. . G. (2012). Pengaruh Kinerja Keuangan terhadap Nilai Perusahaan dengan Kebijakan Dividen sebagai Variabel Pemoderasi. Jurnal Manajemen, Strategi Bisnis, Dan Kewirausahaan, 6(2), 130-138. https://doi.org/10.1017/CBO9781107415324.004

[32]. Mangantar, M., \& Sumanti, J. C. (2015). Analisis Kepemilikan Manajerial, Kebijakan Hutang Dan Profitabilitas Terhadap Kebijakan Dividen Dan Nilai Perusahaan Pada Perusahaan Manufaktur Yang Terdaftar Di Bei Analysis. Jurnal EMBA, 3(1), 1141- 1151 .

[33]. Martono, A. H. (2006). Manajemen Keuangan (Kedua). Ekonisia.

[34]. Mery, K. N., ' Z., \& Kurnia, P. (2017). Pengaruh Likuiditas, Leverage Dan Profitabilitas Terhadap Nilai Perusahaan Dengan Kebijakan Dividen Sebagai Variabel Moderasi Pada Perusahaan Pertambangan Yang Terdaftar Di Bursa Efek Indonesia Tahun 2011- 2014. Jurnal Online Mahasiswa Fakultas Ekonomi Universitas Riau, 4(1), 2000-2014.

[35]. Navissi, F., \& Naiker, V. (2006). Institutional ownership and corporate value. Managerial Finance, 32(3),247-256.

[36]. Nurhayati, M. (2013). Profitabilitas, Likuiditas Dan Ukuran Perusahaan Pengaruhnya Terhadap Kebijakan Dividen Dan Nilai Perusahaan Sektor Non Jasa Mafizatun. Jurnal Keuangan Dan Bisnis, 5(2), 144-153.

[37]. Padnyawati, K. D., \& Kusumawati, N. P. A. (2018). Pengaruh Struktur Kepemilikan Manajerial Pada Nilai Perusahaan Dengan Kebijakan Dividen Sebagai Variabel Intervening. 2018, 1-23.
[38]. Raharjaputra, H. (2009). Manajemen Keuangan Dan Akuntansi. Salemba Empat.

[39]. Rahmantio, I., Saifi, M., \& Nurlaily, F. (2018). Pengaruh Debt To Equity Ratio, Return On Equity , Return On Asset Dan Ukuran Perusahaan Terhadap Nilai Perusahaan ( Studi pada Perusahaan Pertambangan yang Terdaftar di Bursa Efek Indonesia Tahun 2012-2016). Jurnal Administrasi Bisnis (JAB), 57(1), 151-159.

[40]. Riyanto, B. (1995). "Dasar-Dasar Pembelajaran Perusahaan" (Keempat). Gajah Mada.

[41]. Rochmah, S. A., \& Fitria, A. (2017). Pengaruh Kinerja Keuangan Tehadap Nilai Perusahaan: Kebijakan Dividen Sebagai Variabel Moderating. Jurnal Ilmu Dan Riset Akuntansi, 6(3), 998-1017.

[42]. Sambora, M. N., Handayani, S. R., \& Rahayu, S. M. (2014). Pengaruh Leverage Dan Profitbilitas Terhadap Nilai Perusahaan. Jurnal Administrasi Bisnis, $8(1)$, 1-10. https://doi.org/10.1017/CBO9781107415324.004

[43]. Sartono, A. (2002). Financial management Applications and Theory. BPFE.

[44]. Sudana, I. M. (2011). Manajemen Keuangan Perusahaan Teori dan Praktik. Erlangga.

[45]. Sugiyono. (2007). Metode Penelitian Bisnis. Alfabeta.

[46]. Sugiyono. (2011). Metode Penelitian Kuantitatif, Kualitatif dan R\&D. Alfabeta.

[47]. Tahu, G. P., \& Susilo, D. D. B. (2017). Effect of Liquidity , Leverage and Profitability to The Firm Value (Dividend Policy as Moderating Variable) in Manufacturing Company of Indonesia Stock Exchange. Research Journal of Finance and Accounting, 8(18), 89-98.

[48]. Taslim, F. A. (2016). Pengaruh Rasio Likuiditas, Aktivitas, dam Profitabilitas Terhadap Nilai Perusahaan Dengan kebijakan Dividen Sebagai variabel Intervning (Pada Perusahaan Manufaktur yang Terdaftar Di BII Periode 2010-2014). Jurnal Equilibrium, x(1), 1829 5517.

[49]. Tui, S., Nurnajamuddin, M., Sufri, M., \& Nirwana, A. (2017). Determinants of Profitability and Firm Value: Evidence from Indonesian Banks. IRAInternational Journal of Management \& Social Sciences (ISSN 2455-2267), 7(1), 84. https://doi.org/10.21013/jmss.v7.n1.p10

[50]. Ventje Ilat, Novi Swandari Budiarso, H. R. N. W. (2019). TRUST VALUE OF A DIVIDEND: AN EVIDENCE FROM INDONESIA. Accountability, 08(01), 17-28.

[51]. Vintilă, G., \& Gherghina, Ş. C. (2015). Does ownership structure influence firm value? An empirical research towards the bucharest stock exchange listed companies. International Journal of Economics and Financial Issues, 5(2), 501-514.

[52]. Wida, N. P., \& Suartana, I. W. (2014). Pengaruh Kepemilikan Manajerial Dan Kepemilikan Institusional Pada Nilai Perusahaan. E-Jurnal Akuntansi, 9(3), 575-590. 
[53]. Winarno, W. W. (2007). Analisis Ekonometrika dan Statistika dengan Eviews. Yogyakarta: UPP STIM YKPN.

[54]. Wira. (2011). Analisis Fundamental Saham. Exceed.

[55]. Wulandari, D. R. (2013). Pengaruh Profitabilitas, Operating Leverage, Likuiditas Terhadap Nilai Perusahaan Dengan Struktur Modal Sebagai Intervening. Accounting Analysis Journal, 2(4), 455- 463.

[56]. https://doi.org/10.15294/aaj.v2i4.4172

[57]. https://id.investing.com/

[58]. https://investasi.kontan.co.id/

[59]. https://id.investing.com/indices/idx-cons.-property--real-estate-historical-data

[60]. www.idx.co.id 